\title{
CLOUDLAND, STRONZOLAND, BRISBANE: URBAN DEVELOPMENT AND ETHNIC BILDUNG IN VENERO ARMANNO'S FICTION
}

\author{
Jessica Carnie1
}

\begin{abstract}
The evolving urban landscape of Brisbane becomes a significant presence in Venero Armanno's fiction, distinct from the often more documented sites of Sydney, Melbourne. The use of Brisbane as the setting for Armanno's novels is significant in that this city, like the characters he creates within it, is often seen as being in search for its own culture and identity, having grown up in the shadow of the reputedly more cosmopolitan eastern coast capital cities of Sydney and Melbourne. Brisbane's recovery from its somewhat shady past involving corrupt government and law enforcement echoes the journey upon which Armanno's protagonists embark. Furthermore, Brisbane, especially the suburbs of New Farm and Fortitude Valley featured in Armanno's works, acts as a symbolic Little Italy to which the protagonists might retreat in search of their ethnic beginnings. Questions of community and identity are intrinsic to the urban landscape through which the protagonist travels in their quest for Bildung. Focussing on the three of Armanno's fictional works set in the city of Brisbane and using critical definitions of Bildung and the notion of ethnic Bildungsromane, this paper aims to examine the parallel development of the Italian Australian protagonists and their urban environments.
\end{abstract}

Brisbane is so sleepy, so slatternly, so sprawlingly unlovely! I have taken to wandering about after school looking for one simple object in it that might be romantic, or appalling even, but there is nothing. It is simply the most ordinary place in the world.

(Malouf, 1975:51-52) 
In the growing body of literature and cinema by and about ItaloAustralians, and in contemporary Australian literature and film as a whole, the large and cosmopolitan cities of Sydney and Melbourne are undoubtedly more familiar settings for most consumers, regardless of their own location or point of origin. Brisbane, the state capital of Queensland characterised in Malouf's (1975:9) Johnno as an 'overgrown country town', is less publicised and less romanticised and thus less familiar to the Australian imagination. Although often seen as a cheap alternative for film and television productions (I distinctly remember the solitary double-decker bus that wended its way through the more Victorian-looking buildings in the city in an attempt to make it look like London for the filming of the Mission Impossible television series in the early 1990s), it has also been knocked back in the casting of its own character in adaptations of novels set in Brisbane, as was the case for the feature length film adaptation of Andrew McGahan's critically acclaimed novel, Praise, which was filmed in Sydney. Even the author whose works are the subject of this paper, Venero Armanno, considered transferring the setting of his novel, Firehead, from Brisbane to New York for a possible film version. Although such transfers of setting prove the universality of the stories involved, what is lost is the way in which the authors use certain cityscapes as more than backdrops, and as characters in themselves.

Of Armanno's six published novels, three are predominantly set in Brisbane. These three texts, Romeo of the Underworld (1994), The Volcano (2001) and Firehead (1999), will be the focus of this paper. Armanno's use of Brisbane as the setting for his novels is significant in that this city, like the characters he creates within it, is often seen as being in search of its own culture and identity, having grown up in the shadow of the reputedly more cosmopolitan eastern coast capital cities of Sydney and Melbourne. Brisbane's recovery from its somewhat shady past involving corrupt government and law enforcement, and the destruction of heritage-listed landmarks such as Cloudland Ballroom, echoes the journey upon which Armanno's protagonists embark. By reading each text as a Bildungsroman, that is, novel of 
development, formation or coming-of-age, thus using development and growth as a significant theme, the evolution of Brisbane's urban landscape and cultural character can be traced alongside the development of the protagonists, Sam Capistrano (Firehead), Romeo Costanzo (Romeo of the Underworld), and Emilio and Mary Aquila (The Volcano). I argue that the setting of Brisbane is, in fact, integral to the Bildung (development) of the characters because of the way in which the characters interact with their urban environment along their road to maturation. Furthermore, Brisbane, particularly the inner city suburbs of New Farm and Fortitude Valley, acts as a symbolic Little Italy to which Armanno's protagonists might retreat in search of their ethnic beginnings.

A brief explanation of Bildungsromane is necessary before further examining Armanno's works in this context. The traditional Bildungsroman typically features a male protagonist moving from country to city, encountering problems and people along the road to his maturation (Bona, 1999b:322-323). This journey of development involves a journey away from the family as the protagonist seeks to establish their self as a modern individual, successfully integrated into modern society. Even the more generous traditional definitions of the Bildungsroman generally exclude the possibility of female protagonists or protagonists not of the ethnic, religious or cultural majority. Recent critical examinations of this genre however, have highlighted its usefulness for reading the formation and development of gender and ethnic identities. ${ }^{1}$ Novels depicting the conflict and confusion about, and search for, ethnic identity can be effectively allocated within this traditional genre of the Bildungsroman, under the tentative sub-genre of the 'ethnic Bildungsroman'. It is within this

\footnotetext{
1 For further reading on gendered and ethnic Bildungsromane, see Bona, M.J. (1999b) The Italian American Coming-of-Age Novel, in The Italian American Heritage: A Companion to Literature and Arts (Ed, D'Acierno, P.) Garland Publishing, New York, London: 322-328, Bona, M.J. $\left(1999^{\circ}\right)$ Claiming a Tradition: Italian American Women Writers, Southern Illinois University Press, Carbondale, Fraiman, S. (1993) Unbecoming Women: British women writers and the novel of development, Columbia University Press, New York, Feng, P.-c. (1998) The Female Bildungsroman by Toni Morrison and Maxine Hong Kingston: A Postmodern Reading, Peter Lang, New York, Kushigian, J.A. (2003) Reconstructing Childhood: Strategies of reading for culture and gender in the Spanish American bildungsroman, Bucknell University Press, Lewisburg.
} 
idea of the ethnic Bildungsroman that I situate my analysis of Armanno's texts together with an awareness of the role of gender in Bildung. ${ }^{1}$

\section{Cloudland: 'All we leave behind is the memories'²}

As the years go by, the old neighbourhoods change. Whole families move away and with them go the stories. (Gardaphe, 2004:151)

Destroyed early in the morning of November 71982 by the notoriously mercenary demolitionists, the Deen Brothers, Cloudland Ballroom was an important social centre in Brisbane. Completed in 1940 and opening in August of that year, Cloudland was originally known as Luna Park Brisbane, located on Cintra Hill in the inner city suburb of Bowen Hills. The ballroom featured a funicular to transport its guests up the steep hill on which it was perched and was to incorporate an amusement park, but these plans were never completed due to events of the Second World War and the occupation of the site by the United States army (Fisher, 1991:57; McBride \& Taylor, 1997:47). After the war, the ballroom was sold and reopened in 1947 as Cloudland Ballroom. Cloudland witnessed generations of dancing socialites, migrants and teenagers, university examinations, flea markets and rock bands. One of over sixty heritage-listed buildings demolished in Brisbane between the mid 1970s and early 1990 whilst the anti-heritage, pro-development National Party were in power in Queensland, Cloudland's demolition is seen as one of the most significant, together with the BelleVue Hotel and the Queen Street Commonwealth Bank. Fisher (1991:55) suggests it was these

\footnotetext{
1 With the exception of Mary Aquila, Armanno always uses male protagonists who frequently narrate the story in first person. Deliberate narratorial confusion in The Volcano blends the subject, narrator and protagonist positionings of Mary and Emilio, although I would argue that Armanno never succeeds in transforming Mary from object (as she is originally characterised in Romeo of the Underworld) to subject or protagonist. This is further examined in my PhD thesis on Italian Australian Bildungsromane, from which this paper has been drawn and developed.

2 Deen Brothers demolition company motto.
} 
demolitions that transformed the 'prewar town...into a nondescript high-rise city.'

Cloudland has played a significant role in Brisbane's social and cultural past, and is a notable presence and absence in Armanno's fiction. Throughout both Romeo of the Underworld and The Volcano, generally read as part of the 'Romeo trilogy' started by The Lonely Hunter (1993), ${ }^{1}$ Armanno highlights its importance to migrants of the 1950s and to their teenage children growing up in the 1970s. He reflects Brisbane's nostalgia for the lost landmark, lamenting its loss and sharply criticising the construction of an ultra-modern apartment complex on its former site, yet he challenges the innocence of Brisbane's memories by depicting it as a site of underhand dealings and under-age drinking.

At the beginning of Romeo of the Underworld, as Romeo Costanzo's plane circles above Brisbane with smoking engines, he scans the landscape outside his window for the landmarks of his youth spent in Brisbane only to find that the final one, and the most important, has been replaced by modern townhouses. Cloudland's absence provokes both anger and nostalgia in Romeo:

For once upon a time at the peak of Bowen Hills' hillock there was a place we'd go for music and dancing and beer, and for girls. A huge and ornate structure from a bygone era, that Cloudland Ballroom, and never was a place so properly named. You saw it from all over Brisbane, perched on its hill with its neon lights more colourful than anything in the evening sky. The ballroom always seemed so kind of nice, so magical. It must have burned to the ground, a Brisbane tragedy, for no one would knock such a place down for anything as crass as commercial housing. The red lights of Cloudland's central dome always made me think of the

1 The Lonely Hunter is set in Sydney and therefore is not included in this paper. It is due to the events in this first novel that the character of Romeo Costanzo retreats to Brisbane. 
silhouette of a volcano - the active Mt Etna, of course. Its sprung wooden dance floors used to make me think of the canvas floor of the wrestling ring, bouncing up and down, up and down, ready for sparring, skirmishing, for the beery-dreamy love match that would start when you latched onto some new Friday night girl. (Armanno, 2001a:12)

This nostalgic description of Cloudland launches Romeo into a flashback of drinking and dancing there in 1976 with his best friend Johnny Armstrong on the night that they met Monica Aquila, who is at the source of Romeo's dilemma. The likeness he draws between 'the red lights of Cloudland's central dome' and Mt Etna establishes a parallel between Cloudland, Romeo's Sicilian origins and the restaurant, Il Vulcano, run by Monica's parents, which was burnt to the ground by her father Michele while Monica was still inside. Romeo's assumption that Cloudland must have accidentally burned to the ground foreshadows his discovery of Monica's own fiery demise.

Armanno later creates an explicit connection between Cloudland and Sicilian migrants' sense of home and place when Monica's father Michele also likens Cloudland to Mt Etna:

'Guardi.' I follow his pointing finger toward Cloudland at the top of the hill. 'Etna,' he says, 'Etna with a fire that never goes out. It's the only thing you can see, day and night, the volcano always there above you. Always on fire in the belly, always with fire coming out of its mouth. We came here and saw Cloudland and we felt like we were home again. So we wrote to our friends and our relatives and they came and they stayed too.'

(Armanno, 2001a:128)

Migrants' experiences and memories of Cloudland are further explored in The Volcano, allowing us to contrast Romeo's Cloudland of the 1970s with Emilio and Michele's Cloudland of the 1950s. Somewhat echoing an earlier description of a reddened night sky 
outside Emilio Aquila's volcanic lair in Sicily (Armanno, 2001b:287), Cloudland is described thus:

In the Cloudland Ballroom Emilio looked from the holy city of stars, which were the multicoloured lights set so high amongst the vast colonnades, the brocaded royal blue and gilt ceilings, the leadlight dome, then he spun Desideria into his arms. ...Mansion of music, palace of dreams: in those days the price of admission was two shillings per adult. (Armanno, 2001b:358)

It is during this, his 'debut' at Cloudland, that Emilio meets Oscar Sosa, the dark stranger whose assistance eventually embroils both Emilio and his friend Rocco Fuentes in Brisbane's underworld. In many regards, the charismatic Sosa is portrayed as a devil-like character and, just as Emilio once stole Desideria/Proserpina into his volcano/Hades, likewise does Sosa eventually steal Emilio into Cloudland's Members Only room.

Although each of the novels comprising the Romeo trilogy are easily read as individual narratives, certain images recur throughout all three texts that act to unite them as a whole. The image of the volcano, specifically Mt Etna, is certainly one of these images. As I have observed above, Romeo's description of Cloudland as a volcano establishes a parallel between the ballroom, his Sicilian origins and the Aquilas' restaurant. As its title reveals, The Volcano constantly draws upon imagery and stories relating to volcanos, specifically Mt Etna. As Michele Aquila points out, Cloudland, in Armanno's fiction, with its red dome glowing from its vantage point on the top of Cintra Hill, reminds Brisbane's Sicilian migrants of their homeland and serves as an enticement for future migrants - they will not have to leave the volcano for it will still be there when they arrive in Australia. Although Cloudland was by no means a social centre exclusive to migrants, Armanno represents it as an important one in his fiction and a beacon to which his characters are drawn and in close proximity to which they create their own Little Italy. 


\section{Stronzoland: Brisbane as a Little Italy}

'In the new age, Little Italy can be anywhere.'

(Viscusi qtd. In Gardaphe, 2004:157)

Italian settlement in Brisbane was particularly concentrated in the inner city suburbs of New Farm and Fortitude Valley, both of which feature prominently in Armanno's fiction. These areas remained a popular site for Italian settlement well into the 1970s, after which Italian migration to Australia began to wane and those that had settled there soon relocated to the outer suburbs. Although some remnants of an Italian presence remain in various cafes, restaurants, specialty stores and delicatessens, the area has not, to a large extent, been maintained or cultivated as a Little Italy in the same manner as Sydney's Norton Street in Leichhardt or Lygon Street in the Melbourne suburb of Carlton. Given such, it is important to consider these suburbs not as a physical Little Italy but as a symbolic Little Italy.

Aiming to construct San Diego's Little Italy as a third space, Fiore (1999:93) suggests that we look at Little Italy 'as a spatial laboratory of ideas, dreams, and practices that defy any binary or exclusionary conception of space (historical preservation vs. utilitarian adaptation), and allow for a more flexible definition of urban space, especially in consideration of the complex ethnic history of the area.' This understanding of Little Italy allows us to construct such spaces from memory and storytelling, therefore is most amenable to literary reconstructions of this ethnic space. Gardarphe's (2004:153) arguments support this reading. He writes, 'Historical and sociological approaches to preserving Little Italy are limited to what is physically there or what was recorded that was there. Free of these restrictions are the literary representations that are the result of images conjured from memory.' In an analysis of 'Little Italies' as settings in Italian American novels, Boelhower (1999:62) argues that the protagonist's 'return to [their] childhood world (in form of a descriptive narrative of the Italian community)...allows [them] to shed light on [their] present condition of existential bewilderment.' In 
Armanno's novels, Brisbane plays the same role as the Little Italies of Italian American literature. We see in these novels the return of the characters to the sites of their youth and memories of a strong ItaloAustralian presence in these locations.

In Romeo of the Underworld, Romeo makes an explicit connection to his mental and emotional state and his presence in Brisbane. The opening chapter, entitled "Stronzo in a Stronzo Land", opens with rumination upon the word stronzo:

Stronzo is a seriously Italian, Italian type word. More so when used in one of the Southern dialects, preferably Sicilian....It's best to have too much to drink before you utter the word, it's best to ache to the very core of your bones and, if you can manage it, to have not slept well for longer than you can remember. Then the word takes on its legitimate meaning and, when applied inwardly, with great personal insight, describes that gut-queasy sensation of realising you've made a mess of not only your own life but the lives of those who have been luckless enough to become intimate with you. (Armanno, 2001a:1-2)

This chapter ends with Romeo thinking as he falls asleep on this, his first night back in Brisbane, 'Stronzo in a stronzo land' (Armanno, 2001a:32). The connection between his 'stronzo' state of mind and his geographical location is more explicitly drawn later in the novel when, left with only five dollars to get home after a night on the town, he ponders, 'How far would that get me through Stronzoland?' (Armanno, 2001a:50). Taking a cab as far as his money will allow, Romeo walks the remaining distance home, unafraid of passing cars and fellow pedestrians, and trapped in his own thoughts: 'Oh, here in Brisbane we walk without any fear of each other at all. Why should I choose to call it Stronzoland? That name was only right for the terrain of my heart' (Armanno, 2001a:50). Romeo's state of nostalgia and discontent, while an ongoing problem established in the previous 
novel, The Lonely Hunter, is expressed through his perception of his urban environment.

As the history of Romeo's residence in Brisbane in 1976 unfolds throughout the novel, it becomes evident that his interactions with the Aquila family and his friendship with Johnny Armstrong have had repercussions throughout his life, and further elucidates the events that occurred in The Lonely Hunter. In this previous novel, Romeo often seeks to shrug off the cultural burden of his Sicilian background, yet succumbs to it after every resistance. He accepts a job in a factory because he needs it, despite feeling resentful that he has obtained it through some cumpare of his parents' that he has never met. He also marries a woman of Italian descent, despite vowing he never would do so as it would please his parents too much. Although Anna is not entirely the 'good Italian girl' that his parents would have hoped for, they are satisfied simply because she is Italian and Romeo is displeased that he has brought about this satisfaction for them. An integral part of Romeo's Bildung in the first novel is his departure from his parents' home where he has lived since Anna's suicide. Having dealt with one aspect of his experience of his Sicilian heritage - that is, his failed 'Italian' marriage - it is almost fitting that he should return to Brisbane to reconcile the other aspect, that of his idealisation of Monica as the 'Italo-Australian princess' (Armanno, 2001a:90), echoed in his later relationships with Anna and Mary.

Although his interactions with his family affect his life decisions and experiences in Sydney, his Sicilian Australian ethnicity and identity are more strongly played out in Brisbane. The scenes from his youth in Romeo of the Underworld serve to explain his reluctance to be a good Italian boy in The Lonely Hunter. A wayward youth, Romeo runs away to Queensland and strikes a compromise with his parents that he will live with his middle-aged cousins in New Farm and complete his final year of school. He constantly tries to downplay his Italian heritage, once bluntly rebuking Michele Aquila's claims to compatriotism with 'Nuh. I'm an Aussie' (Armanno, 2001a:127), yet finds himself drawn to Monica Aquila and her family's intrigues. On the surface they appear to be the Italo-Australian success story - they 
own a top restaurant and their intelligent daughter seems destined for university and white-collar greatness - but eventually the cracks begin to show. Beautiful Gloria Aquila is tiring of her drunken husband and Michele's alcoholic haze pushes him further and further into a dark depression shaped by fierce superstition. Monica jeopardises her future by taking on both Romeo and Johnny Armstrong as her socially unacceptable lovers, and falls pregnant to the latter. The ItaloAustralian dream, so to speak, is revealed to be a sham but is not completely destroyed until Gloria leaves Michele for another (Australian) man, wresting control of the business from him, and Michele, in an act of revenge, burns down Il Vulcano with Monica inside it. Once a hub of the Italo-Australian community and culture where people "came to eat pasta and meet Italian and Sicilian migrants just like themselves' (Armanno, 2001b:168), Il Vulcano is moved to a prominent riverside location outside of New Farm and Fortitude Valley: it is removed from Little Italy and gentrified in the process.

The Volcano also evokes a sense of the community that would have existed in New Farm during the 1950s and that is suggested by the restaurant, Il Vulcano, in Romeo of the Underworld. Emilio, however, wryly critiques this idea of community as being somewhat affected: 'All the Sicilians in Brisbane were calling one another cummare or compare these days, really hamming it up sometimes so that everyone was clear about how much affection they felt for one another' (Armanno, 2001b:384). The text is littered with short descriptions indicating a strong Italian presence in the area, such as the proximity of neighbours, the gatherings for wine, cards and gossip and the existence of Italian food stores and delicatessens. A passing reference to biscotti bought at 'the struggling Sellano Delicatessen' demonstrates the availability of ethnic foods at the same time as it foreshadows the weakening of the Italian presence as a Little Italy in the suburb of New Farm.

Whilst Romeo does not return to a physical Little Italy, his return to Brisbane signals a return to a symbolic Little Italy. In a sense, his interactions with the prominent and successful Aquila family become representative of his interactions with the greater Italo-Australian 
community and his Italian/Sicilian Australian identity is bound up in the Aquilas' perception of him. In order to resolve his identity as an Italo-Australian male, Romeo must acknowledge the way in which his idealisation of Monica has impacted upon his life and his relationships with women, particularly Anna and Mary, and must orchestrate a catharsis for Gloria, Michele and Mary Aquila. Emilio, however, returns to Little Italy in his memories as he recounts his story to Mary. His departure from this symbolic space occurs upon his agreement to work for Oscar Sosa. He no longer dances with his friends in Cloudland's main ballroom but lounges in the Members Only area with Sosa and his minions. It is through his connection with Mary Aquila and her own search for a sense of her origins that allows Emilio to return to a symbolic Little Italy and to participate in cultural maintenance through his story, despite the fact that he has never left the physical space of New Farm.

\section{Brisbane: the background protagonist}

Brisbane has experienced an important transformation over the last decade. According to some commentators, it was during the 1980s that Brisbane finally shed its ramshackle, sleepy town image and 'came of age'. (Caulfield \& Wanna, 1995:x)

Despite the representation of Brisbane between the 1950s and 1990s available in Romeo of the Underworld and The Volcano I would like, in this final section, to focus predominantly upon Firehead because of the way in which its structure distinctly and conveniently reflects the three decades over which, as Caulfield and Wanna observe above, it is believed to have 'come of age'. This novel, I believe, best brings together some of the observations made above and best displays the parallel development of both human and urban protagonists.

Structurally, the text is divided into three parts, each corresponding to the years 1975, 1985 and 1995 . It relies less on the narrative techniques of chronological fracturing and flashback prominently featured in the other texts, allowing the reader to access the 
protagonist's thoughts contemporaneously. It is, of all of Armanno's novels, perhaps that which most resembles the traditional structure of the Bildungsroman, as we follow Sam Capistrano from adolescence, into young adulthood and then into maturity. We also follow his journey from New Farm's Little Italy to a high-rise bachelor pad on the other side of town, to his young family's home in the outer suburbs. Like the protagonist of Romeo of the Underworld, Sam's development hinges upon the acceptance and release of his idealisation of a young Italo-Australian female and the catharsis of past anguish.

Whitlock argues that Queensland or Brisbane narratives:

by no means universally glorify the local. However [these narratives] do cast it in terms of a retrospective, reading Queensland regions spatially in terms of a lost innocence and simplicity, a wilderness space which cannot be recaptured. Even when the urban space enters Queensland narratives, it retains the qualities of wilderness, impermanence and excess. (1994:75)

Loss of innocence is certainly a theme within Armanno's work, particularly Firehead; the first part begins with lyrical, dreamy language that evokes innocence, simplicity and humble, romantic beginnings: 'We were to live side by side in an urban forest of deciduous trees, where crickets and cicadas sang their croaky songs and sparrows and starlings dive-bombed our heads whenever we played our backyard games; how would we ever forget such beginnings?' (Armanno, 1999:4). Armanno creates an image of New Farm as an 'urban forest' in which children play and, as the narrative eventually reveals through Gabriella's disappearance, in which they may become lost. Sam, as narrator, describes his New Farm neighbourhood upon the arrival of recent immigrants, Gabriella Zazó and her family:

She came to our little corner of Heaven in the month of June in the year of 1975, on a Friday the thirteenth, the 
black day. ...she'd come into my corner of the world with her family all the way from that piece-of-dirt nothing place on the toe of Italy, called Sicily [...] a perfectly foreign family unit fresh-moved to the southern hemisphere, the island continent. To Queensland and to Brisbane, to the suburb of New Farm and my big dreamy street, Merthyr Road, corner of the lushly green Abbott Street. (Armanno, 1999:3-4)

Although it is given a precise location in relation to the rest of the world and, most significantly, in relation to Sicily, New Farm is constructed as a fertile urban locale, teeming with birds, insects and life. It is also constructed as a safe place. New Farm Park, a large parkland by the river that became notorious in the 1980s and 1990s for its lack of nocturnal safety due to unsavoury characters lurking in the darkness, is described here as a place where 'you could go down the tree-lined laneways... and even walk by the glittering river just to watch the ferries and be pretty certain no deadshit would come and stick a knife in your back or want to stomp on you just for something interesting to fill his evening' (Armanno, 1999:38).

Like The Volcano, this first part of Firehead is littered with references to delicatessens, family gatherings and general references to the large number of Sicilians living in the neighbourhood that combine to create a sense of a Little Italy. When stacks of newspapers from the local shop erratically disappear, Sam and Gabriella develop creative theories to explain their little local mystery, including 'a plot by some racist political group to keep New Farm Sicilians ignorant of the world and Australian events and hence out of the greater running of the country' (Armanno, 1999:12); the children's imagined victimisation of the local Sicilian population indicates both the significance of this population and their perception that there exists a sense of community and cohesion, further supported by their construction of the 'Australian' population as other. Perhaps the strongest indication of New Farm's Little Italy in 1975 is played out through the role of Pietro Pierucci, a local police officer who was born in Sicily and migrated to Australia as a child. Sam describes him as 
'our local hero' (Armanno, 1999:11) and as 'our local guardian angel' (Armanno, 1999:25), later explaining: 'The thing is, Pietro in Italian means Peter in English but more than that pietro is the word for rock and that was exactly what that young man was to the Sicilian families of those days, the rock upon which they understood the solid foundation of Australian law' (Armanno, 1999:29). Pietro Pierucci is the self-appointed protector of the local Sicilian community and the medium through which the Australian law is interpreted. When Sam disappoints Pierucci by stealing from the local Kmart with his best friend Tony Solero, Sam realises that the police officer's look was 'half anger and half love and it struck me there and then the way it had never struck me before that that was exactly the way he looked at every one of us in those dreamy New farm days' (Armanno, 1999:30). Pierucci's supervision of the community can be read as an attempt to prevent significant damage to or destruction of Little Italy through a disintegration of values (such as criminal activities) or unfair treatment (such as discrimination against Italians by the host society) but he cannot prevent its slow disintegration through class mobility and migration to outer suburbs. Consequently, he is unable to continue in his role when he fails to protect Gabriella Zazó whose disappearance becomes symbolic of the disintegration and loss of innocence of this Little Italy.

The qualities of impermanence and excess suggested by Whitlock above manifest themselves in the second part, set in 1985, ten years after Gabriella's disappearance. Sam is now twenty-five and running a nightclub, La Notte, with the Solero brothers, located on the site of Nocturne, the brothel where Gabriella was last seen. The replacement of Nocturne's former 'palatial, colonial splendour' (Armanno, 1999:58) by a modern steel and glass construction is placed within the context of the 'rapidly disappearing colonial architecture of Brisbane's past' (Armanno, 1999:95) previously explored in Armanno's depictions of Cloudland and its demolition. Although in 1975 Brisbane was already home to police corruption, illegal activity and the demolition of heritage-listed buildings, Sam remained largely innocent of the city's seedier side except through half-heard tales of Lino Solero's misadventures with his friends in Fortitude Valley on a 
Saturday night. Where the text's first part portrayed a world of family and a slowly dissipating community, the second part moves into a fast-paced world of sleeping during the day and partying through the night, of an urban jungle comprised of high-rises and an abandonment of Little Italy and all it represented. Yet Sam remains largely unfulfilled by his lifestyle and the beautiful women he beds never match his ideal that is on constant display in the photos of Gabriella that decorate his apartment walls.

Although technically an adult, Sam has not yet embraced the responsibilities of adulthood and his lingering obsession with Gabriella represents his reluctance to let go of the dream of childhood despite having long ago lost its innocence. It is the nightclub singer Irina Luna that awakens Sam to his obsession and urges him to resolve his past for the sake of his own future happiness. A dream of Gabriella's room, a bomb shelter under the Zazó's wine cellar, shared by her grandfather, Enrico Belpasso, leads Sam, accompanied by Irina, to return to his 'little corner of Heaven' to which he has not returned in almost a decade. Sam is struck by the changes to his old neighbourhood:

I stared at the new bits of Brisbane landscape. Here an apartment building where the old service-station driveway Tony Solero and I learned to roller skate in used to be. There a snazzy café-bar-restaurant where yesterday there was a laundromat. Some Yugoslavian girl older than me used to work there, smelling always of Pears shampoo and 4711 cologne. With unlikely charm and priapic perseverance one closing time the seventeenyear-old me got seventeen seconds to feel the entire firm mystery of her Maidenform D-cups before, laughing, their owner threw me out the back door into the semiindustrial wasteland that used to be that part of the suburb. Now there were apricot-coloured apartment complexes and black and white eateries and polyethnic delicatessens sprouting up on every street corner. New Farm was getting so polished you wouldn't find a dog's 
mess on the footpath or a single catfish in that river that twisted so muddy through the lower reaches of the suburb.

Irina, not Brisbane born and bred, didn't see the changes, the gentrification. She wouldn't have seen them anyway. (Armanno, 1999:174-175)

Sam reads each of the changes through the lens of his past experience and the small but personal milestones. It is possible that when he stresses that Irina would be unable to see the changes in his neighbourhood even if she was from Brisbane, the meaning is ambiguous. Is she preoccupied by her decision to leave her husband for Sam? Is it part of her character to remain unmoved by change in general? Or could she not see the changes unless it had also been her neighbourhood and that service-station driveway was also where she had learned to roller skate? Due to Sam's highly personalised account of the changes, I would argue the latter; to a detached visitor it is simply the way of progress.

Ten years later, however, Sam is himself part of the process of gentrifying New Farm, Fortitude Valley and the adjacent Spring Hill, running the restaurant Notte e Giorno with his parents, again on the site that was Nocturne (the brothel where Gabriella disappeared) and that was La Notte (the nightclub owned by Sam and the Solero brothers). The site's various incarnations create a palimpsest wherein what is imperfectly erased (local Brisbane memory of the brothel where a young Italo- Australian girl disappeared and of the underhand dealings that eventually led to the closure of the nightclub that ruined the lives of promising young Italio-Australian men) is written over (by a successful Italian restaurant) yet exists beneath the layers (through the memory of the Italo-Australian man who runs the restaurant and was involved in the notorious events of the past). The repetition of 'Italo- Australian' here is a deliberate attempt to indicate how Armanno transforms the site into a stage for a drama played out in the Italo-Australian community, depicting its fall (Gabriella's disappearance and the illegal activities of the Solero brothers) and the promise of resurrection (the success of Sam's legitimate, family-run 
business). It also reflects the changing face of Brisbane and of Sam Capistrano - their loss of innocence, their corruption and their redemption.

The novel's conclusion, wherein Sam is reunited with an adult Gabriella who reveals that she ran away to explore herself and the country and to escape a sexual relationship with her grandfather, is interestingly played out on Stradbroke Island, in Brisbane's Moreton Bay. Recalling Whitlock's (1994:75) argument regarding the use of Queensland regions as 'a wilderness space which cannot be recaptured', Sam there encounters such a space and, in the moment in which he achieves Bildung, realises that he cannot stake a claim to Gabriella and return to their past innocence:

the price of having her was too high; what she still carried I'd left behind - all that bitterness and loneliness in the big dreamy streets of our big dreamy past. ...I didn't think it was too romantic to believe that she forgave Belpasso, Pierucci, and our old dreamy streets too, because not to do so would have kept her from finding that thing she'd said she'd always longed for. She wanted belonging, or at least a road that might lead her to that particular corner of Heaven. It didn't make me feel guilty that I'd found a way to beat her there. (Armanno, 1999:397-399)

Gabriella did not succeed in finding a sense of place in the "big old dreamy streets' of New Farm in the same way that Sam did. Her disappearance and her travels around Australia demonstrate her sense of dislocation from her urban environment and her desire to connect with her adopted country; that she will find belonging is hinted at in descriptions of her naturalness when she and Sam are reunited, naked, in the sea and the repetition of the phrase 'a corner of Heaven' (Armanno, 1999:382) in Gabriella's description of her beach on Stradbroke. 


\section{Conclusions}

[The] prospect of self-realisation and identity should be measured metonymically: as the person grows and forms $\mathrm{him} /$ herself, so does the nation, feeling similar growing pains and struggles with rites of passage as the individual. (Kushigian, 2003:17)

To paraphrase Kushigian above and to place her argument within the context of the city, this paper has demonstrated the way in which the city and the person grow and form together and how it is possible, through fiction such as that of Armanno, to reveal the parallel Bildung of city and protagonist. We have seen how Cloudland is used to represent the Sicilian migrants' sense of place and home through its imagined likeness to the volcano, Mt Etna, and how this contributes to the construction of New Farm as a symbolic Little Italy, the demise of which represents the loss of innocence. The protagonists must return to this symbolic space and, through witnessing the changes in the urban environment, are able to reconcile their pasts and accept their ethnic identities. Although the stories of love, loss and redemption told by Armanno cross time and borders, he uses the specific urban setting of Brisbane to further elucidate the thoughts and experiences of his protagonists which reveals the city's own unique story and journey to development.

(University of Melbourne)

\section{References}

Armanno, V. 1999 Firehead, Sydney: Vintage.

2001a Romeo of the Underworld, Sydney: Vintage.

2001b The Volcano, Sydney: Vintage. 
Boelhower, W. 1999 Adjusting Sites: The Italian-AmericanCultural Renaissance, in Adjusting Sites: New Essays in Italian American Studies (Eds. Boelhower, W. \& Pallone, R.) Stony Brook, New York: Forum Italicum: 57-87.

Bona, M.J.

1999a Claiming a Tradition: Italian American Women Writers, Carbondale: Southern Illinois University Press.

1999b The Italian American Coming-of-Age Novel, in The Italian American Heritage: A Companion to Literature and Arts (Ed. D'Acierno, P.) New York, London: Garland Publishing: 322-328.

Caulfield, J. \& Wanna, J

1995 Introduction, in Power and Politics in the City: Brisbane in Transition (Eds. Caulfield, J. \& Wanna, J.) Brisbane: Griffith University: $\mathrm{x}-\mathrm{xx}$.

Feng, P.-c.

1998 The Female Bildungsroman by Toni Morrison and Maxine Hong Kingston: A Postmodern Reading. New York: Peter Lang.

Fiore, T.

1999 Reconfiguring Urban Space as Thirdspace: The Case of Little Italy, San Diego (California), in Boelhower, W. \& R. Pallone (eds.): 89-110.

Fisher, R.

1991 'Nocturnal demolitions': The long march towards heritage legislation in Queensland, in Packaging the Past? Public Histories (Eds. Rickard, J. \& Spearritt, P.) Melbourne University Press:55-69. 
Fraiman, S.

1993 Unbecoming Women: British women writers and the novel of development. New York: Columbia University Press.

Gardaphe, F.L. 2004 Leaving Little Italy: Essaying Italian American Culture, SUNY, Albany.

Kushigian, J.A. 2003 Reconstructing Childhood: Strategies of reading for culture and gender in the Spanish American bildungsroman, Bucknell University Press, Lewisburg.

Malouf, D.

1975 Johnno: A novel. University of Queensland Press, St Lucia.

McBride, F. \&

1997 Brisbane: One Hundred Stories, Taylor, $\mathrm{H}$. Brisbane: Brisbane City Council.

Whitlock, G.

1994 The Child in the (Queensland) House: David Malouf nd Regional Writing, in Provisional Maps: Critical Exxays on David Malouf (Ed. Nettelbeck, A.) Nedlands: The University of Western Australia: 71-84. 